\title{
Expression of oxytocin, oestrogen and progesterone receptors in uterine biopsy samples throughout the oestrous cycle and early pregnancy in cows
}

\author{
R. S. Robinson¹, G. E. Mann², G. E Lamming ${ }^{2}$ and D. C. Wathes ${ }^{1 *}$ \\ ${ }^{1}$ Reproduction and Development Group, Royal Veterinary College, Hawkshead Road, \\ Potters Bar, Hertfordshire EN6 1NB, UK; and ${ }^{2}$ Division of Animal Physiology, School of \\ Biological Sciences, University of Nottingham, Sutton Bonington, Loughborough, \\ Leicestershire LE12 5RD, UK
}

This study examined the expression patterns of oxytocin and steroid receptors in the bovine endometrium during the oestrous cycle and early pregnancy to elucidate their respective roles in the regulation of luteolysis and the maternal recognition of pregnancy. In Expt 1, uterine biopsies were collected from four cows throughout three oestrous cycles each, to provide daily samples. In Expt 2, uterine tissue was collected on days 12, 14, 16 and 18 of the oestrous cycle $(n=20)$ or early pregnancy $(n=16)$. Oxytocin receptor, oestrogen receptor $\alpha$ and progesterone receptor mRNAs were localized by in situ hybridization, and localization of oestrogen receptor and progesterone receptor was confirmed by immunocytochemistry. All three receptors showed time- and cell-specific expression patterns. Oestrogen receptor $\alpha$ increased in all regions at oestrus but high concentrations were also found in the luminal epithelium during the mid-luteal phase and in the deep glands throughout the oestrous cycle. Progesterone receptor expression was higher in the stroma than it was in the types of epithelial cell, and increased expression was observed at oestrus and during the early luteal phase. The cyclical upregulation of oxytocin receptors in the luminal epithelium on about day $\mathbf{1 6}$ was not related to preceding changes in the endometrial expression of either oestradiol $\alpha$ or progesterone receptors. During early pregnancy, oxytocin receptor expression was suppressed. Oestrogen receptor $\alpha$ concentrations increased in the non-pregnant cows and decreased in the pregnant cows between days 16 and 18, but these changes followed rather than preceded the upregulation of oxytocin receptors in the non-pregnant cows. It is concluded that the initial upregulation of oxytocin receptors in the luminal epithelium, which triggers luteolysis, is not associated directly with changes in expression of oestrogen receptor $\alpha$.

\section{Introduction}

The upregulation of endometrial oxytocin receptors plays an important role in the initiation of luteolysis in ruminants (McCracken et al., 1999). The binding of oxytocin to endometrial oxytocin receptor initiates the pulsatile secretion of $\mathrm{PGF}_{2 \alpha}$ and results in luteal regression (Flint and Sheldrick, 1983). Oxytocin receptor gene expression is temporally and spatially regulated in the ovine uterus throughout the oestrous cycle. Oxytocin receptors appear first in the luminal epithelium on day 14 in sheep, increasing to a peak at oestrus (day 0) (Wathes and Hamon, 1993; Stevenson et al., 1994). In cattle, the initial increase in oxytocin receptor concentration occurs between days 15 and 17, preceding luteolysis (Jenner et al., 1991; Mann and Lamming, 1994; Robinson et al., 1999).

During the ovarian cycle, oestrogen and progesterone, presumably acting through their endometrial receptors

*Correspondence

Email: dcwathes@rvc.ac.uk (oestrogen receptor $\alpha$ and progesterone receptor, respectively), influence the timing of upregulation of endometrial oxytocin receptor. For example, in sheep, the administration of a large dose of oestradiol in mid-cycle increased endometrial oxytocin receptor concentrations $12 \mathrm{~h}$ after the injection and initiated luteolysis (Hixon and Flint, 1987). In sheep, oestrogen receptor $\alpha$ concentrations are also upregulated during luteolysis, although it is uncertain whether this upregulation begins before or after the increase in oxytocin receptor in the luminal epithelium (Cherny et al., 1991; Wathes and Hamon, 1993). Conversely, progesterone inhibits oxytocin receptor gene expression during the early to mid-luteal phase (Wathes and Hamon, 1993). However, the effect of progesterone is temporary and after 12 days of continuous exposure to progesterone, the progesterone block to oxytocin receptor upregulation is lost in sheep (Vallet et al., 1990; Wathes et al., 1996). The exact mechanism of oxytocin receptor upregulation in the endometrium is still unknown.

During early pregnancy, the upregulation of oxytocin receptor in the endometrial luminal epithelium is 
suppressed by interferon $\tau$ secreted from the conceptus (Flint et al., 1994; Wathes and Lamming, 1995; Mann et al., 1999). In pregnant ewes, the expression of oestrogen receptor $\alpha$ is also suppressed during early pregnancy and it has been hypothesized that interferon $\tau$ inhibits oxytocin receptor upregulation by inhibiting a preceding increase in oestrogen receptor $\alpha$ expression (Spencer and Bazer, 1995). However, previous reports have indicated that the situation might be different in cows as, on day 16, the presence of an embryo had no effect on oestrogen receptor $\alpha$ mRNA and protein concentrations, but oxytocin receptor mRNA expression was suppressed (Robinson et al., 1999).

The aims of the experiments reported here were: (1) to localize and (2) to compare the expression patterns for oxytocin receptor, oestrogen receptor $\alpha$ and progesterone receptor during the oestrous cycle and early pregnancy in the bovine uterus, and (3) to investigate the effect of pregnancy on their expression. Receptor mRNA localization was performed by in situ hybridization and steroid receptor was detected by immunocytochemistry.

\section{Materials and Methods}

\section{Animals and experimental design}

All experiments were conducted under the Animals (Scientific Procedures) Act 1986.

Experiment 1. Uterine biopsy samples were collected over three oestrous cycles from four Holstein-Friesian nonlactating cows, as described by Mann and Lamming (1994). The biopsy samples were collected on days 14, 15, 16, 17 and 18 of the first cycle, days $6,8,10$ and 12 of the second cycle and days 0 (oestrus), 2, 4, 19, 20 and 21 of the third cycle. The samples were immediately frozen in liquid nitrogen and stored at $-80^{\circ} \mathrm{C}$ for subsequent analysis.

Experiment 2. Twenty-six Friesian-Holstein cows were inseminated at natural oestrus, and a further ten cows were left as uninseminated controls. The cows were killed on one of days 12, 14, 16 or 18 after oestrus, and the uteri were removed and flushed for embryos. Uterine cross-sections, approximately $3 \mathrm{~cm}$ in length, were taken from the horn adjacent to the corpus luteum, and frozen and stored as described above. There were 16 pregnant cows in total, and the non-pregnant inseminated cows and uninseminated controls were combined to form a single non-pregnant group (Table 1).

\section{Measurement of progesterone and oestradiol}

Jugular venous blood samples were collected each day from cows in Expt 1 for subsequent measurement of progesterone and oestradiol concentrations. Progesterone was measured in plasma samples, after extraction with petroleum ether, by radioimmunoassay (Haresign et al., 1975) with antisera obtained from J. B. A. Furr (AstraZeneca plc, Macclesfield). The sensitivity of the assay was $0.3 \mathrm{ng}$
Table 1. Number of cows in each group in Experiment 2

\begin{tabular}{lcccc}
\hline & \multicolumn{4}{c}{ Days after oestrus } \\
\cline { 2 - 5 } & 12 & 14 & 16 & 18 \\
\hline Pregnant & 2 & 5 & 5 & 4 \\
Non-pregnant & 6 & 6 & 4 & 4 \\
\hline
\end{tabular}

$\mathrm{ml}^{-1}$ and the intra- and interassay coefficients of variation were 6.1 and $9.7 \%$, respectively. Oestradiol was measured in plasma using a modified radioimmunoassay kit (Serono Diagnostics, Woking) (Mann et al., 1995). The sensitivity of the assay was $0.5 \mathrm{pg} \mathrm{ml}^{-1}$ and the intra- and interassay coefficients of variation were 7.1 and $10.2 \%$, respectively.

\section{Oligonucleotide probes}

All probes used were single-stranded oligonucleotides of 45 bases in length (Brabaham Institute, Cambridge). Sense probes were always included as negative controls and any signal from these was regarded as non-specific. The oxytocin receptor sense sequence corresponded to the bovine oxytocin receptor gene bases 3504-3548 (Bathgate et al., 1995): 5' TTCGTGCAGATGTGGAGTGTCTGGGATGCCGATGCGCCCAAGGAA 3'.

The oestrogen receptor sense sequence corresponded to the ovine oestrogen receptor $\alpha$ gene bases 564-608 (Madigou et al., 1996): 5' GGCTATGCGGTGCGCGAAGCCGGCCCTCCCGCCTACTACAGGCCA 3'.

The progesterone receptor sense sequence corresponded to the ovine progesterone receptor gene bases 531-575 (Madigou et al., 1995): 5' CTTCTCTCAGTGGTCAAGTGGTCTAAGTCACTGCCAGGTTTTCGG 3'.

\section{Localization of $m R N A$ by in situ hybridization}

The method was based upon that described by Stevenson et al. (1994) and Robinson et al. (1999). The slides from the in situ hybridization were exposed to $\beta$-max hyperfilm (Amersham International, Aylesbury) for 14 days (oxytocin and progesterone receptor) or 24 days (oestrogen receptor).

\section{Photographic emulsions}

Slides previously exposed to X-ray film were coated with photographic emulsion LM1 (Amersham International) as instructed and left at $4^{\circ} \mathrm{C}$ for 3 weeks (oxytocin and progesterone receptor) or 5 weeks (oestrogen receptor). The slides were developed in $20 \%(\mathrm{v} / \mathrm{v})$ phenisol, fixed in 1.9 mol sodium thiosulphate $\mathrm{I}^{-1}$ and counterstained with haematoxylin and eosin to confirm cellular localization of the radioactive signal.

\section{Absorbance measurements}

Absorbance measurements were made using a Seescan image analysis system (Seescan plc, Cambridge) as described by Stevenson et al. (1994). In brief, autoradiographs were 
projected onto a computer screen, the region of interest was encircled and the mean absorbance reading of this area was measured. The background absorbance, from a blank autoradiograph, was first automatically subtracted. The absorbance value for the sense section was subtracted from the corresponding antisense section. One reading was obtained for the complete length of the luminal epithelium, subepithelial stroma and the whole myometrium from each section, and two sections per cow were used. Four readings were obtained from each section for the superficial glands and deep glands, and two sections per cow were used. A mean value of specific hybridization for each animal was then calculated. The limit of detection was taken as an absorbance value of 0.01 .

\section{Immunocytochemical localization of oestrogen and progesterone receptors}

The localization of the oestrogen and progesterone receptors was based on the method described by Wathes and Hamon (1993). The antibodies used were $2.25 \mu \mathrm{g}$ mouse anti-human oestrogen receptor $\mathrm{ml}^{-1}$ (Dako Diagnostics, High Wycombe) and $5 \mu \mathrm{g}$ mouse anti-human progesterone receptor $\mathrm{ml}^{-1}$ (Affinity BioReagents, Neschanic Station, NJ). Mouse IgG $\left(5 \mu \mathrm{g} \mathrm{m}^{-1}\right)$ was used for control sections. The sections were randomly labelled to avoid counting bias and the intensity of the stain determined under a microscope on a scale of 0 (absent) to 4 (very strong).

\section{Data analysis}

The data were always checked for homogeneity of variance using Levene's test and were log transformed if appropriate. If the data still showed non-homogeneity of variance, then a non-parametric test was used. The results were considered significant when $P<0.05$.

Experiment 1. The data were analysed by randomized block ANOVA with day as the fixed factor and cow as the random factor. The error degrees of freedom were adjusted for the repeated measure design using the GreenhouseGeisser Epsilon value. The Greenhouse-Geisser Epsilon value was calculated for each cycle for a particular probe using the repeated measures program in SPSS version 7.0. The data for oxytocin receptor mRNA expression throughout the oestrous cycle were analysed by nonparametric Friedman test because the data showed nonhomogeneity of variance even after data transformation. The data for oestrogen receptor $\alpha$ and progesterone receptor were also analysed by the Friedman test as the data collection is qualitative. If a particular region was missing from the section, the data for the other regions was still included in the data analysis. Any missing values $(<10 \%)$ were estimated using the Anderson equation for estimation of missing data in randomized block designs. Only three cows were used for the analysis of oestrogen receptor $\alpha$ and progesterone receptor concentrations in the luminal epithelium as one cow had a large number of sections without

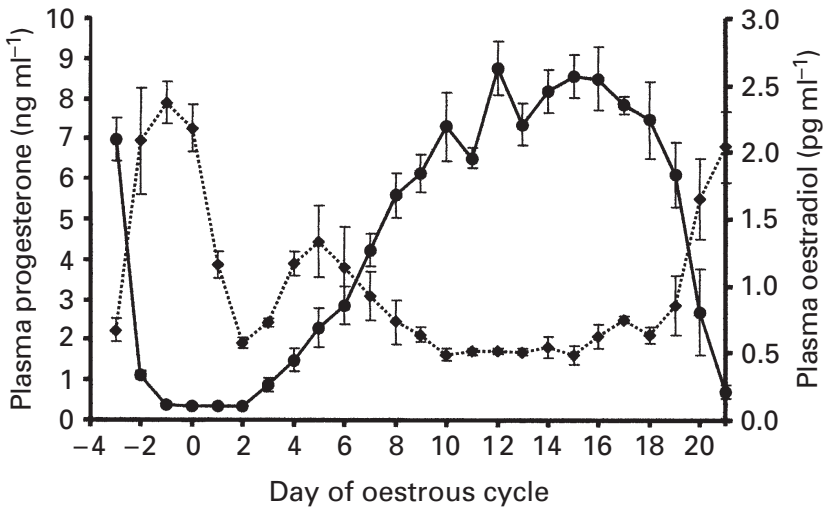

Fig. 1. Concentrations of progesterone $(\bullet)$ and oestradiol $(\bullet)$ in the plasma throughout the oestrous cycle of cows used in Expt 1. The values are the mean \pm SEM concentrations of four cows over three cycles each.

luminal epithelium present. No multiple comparisons were performed after the non-parametric Friedman test, as there was no appropriate test. The differential mRNA expression of each probe in different regions of the uterus was compared using the non-parametric Wilcoxon-Sign test.

Experiment 2. The data on oxytocin receptor and oestrogen receptor $\alpha$ mRNA expression were analysed by full factorial two-way ANOVA with day and pregnancy status as fixed factors using the general linear model procedures of ANOVA in SPSS version 7.0. If there was a significant day, pregnancy status or day-pregnancy status interaction effect, then the Fisher's LSD multiple comparisons were performed to determine where the differences lay.

\section{Results}

In general, the biopsy samples collected during the oestrous cycle in Expt 1 contained luminal epithelium, superficial glands, deep glands and subepithelial stroma, although some of the sections did not have luminal epithelium. Some of the uterine cross-sections in Expt 2 also contained caruncular stroma. Plasma progesterone and oestradiol measurements taken from cows in Expt 1 are shown (Fig. 1). The highest concentration of oestradiol was at oestrus, and values started to increase from luteal phase concentrations on day 19. Another smaller peak concentration was evident on days 4-6, during the first wave of follicular development. Progesterone concentrations started to increase on day 3 after oestrus, reaching maximum concentrations on days 12-18 and starting to decrease on day 19.

\section{Oestrogen receptor $\alpha$ expression throughout the oestrous cycle}

Oestrogen receptor $\alpha$ mRNA was expressed in the luminal epithelium and epithelial cells of the superficial glands (Fig. 2a). Oestrogen receptor $\alpha$ mRNA concentra- 

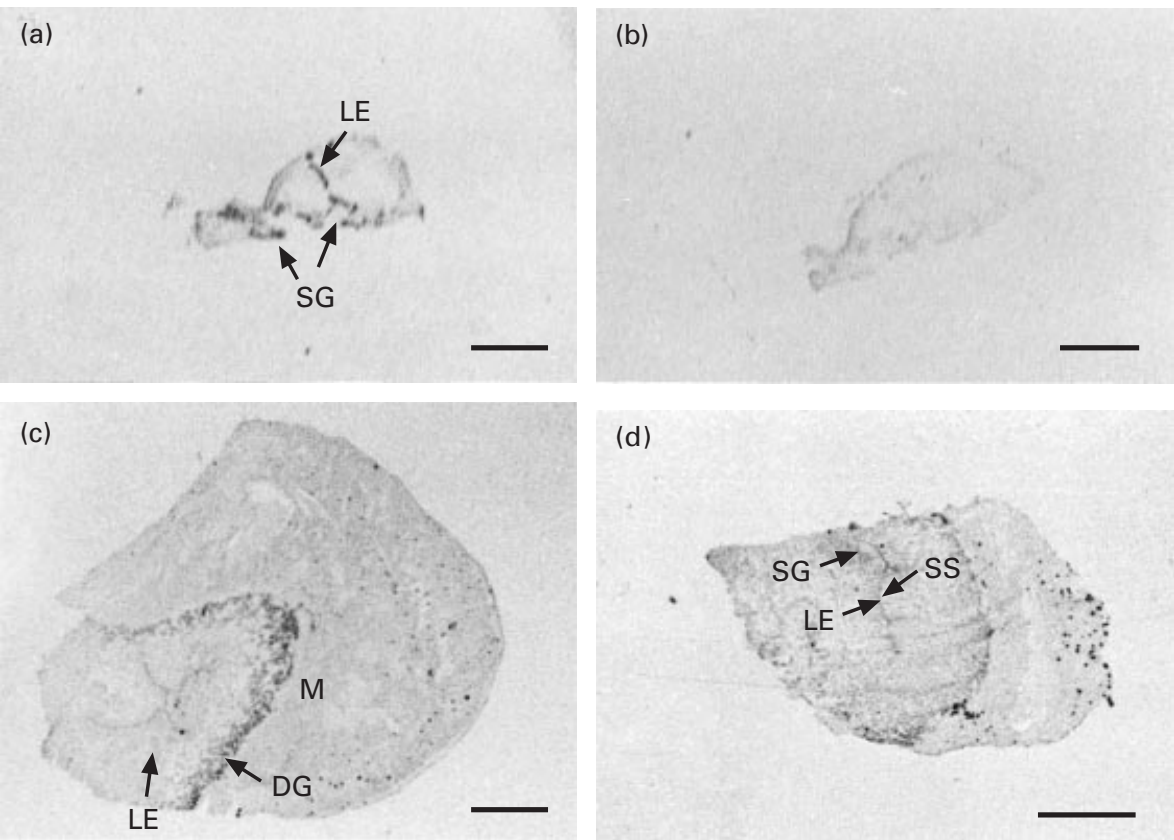

(d)
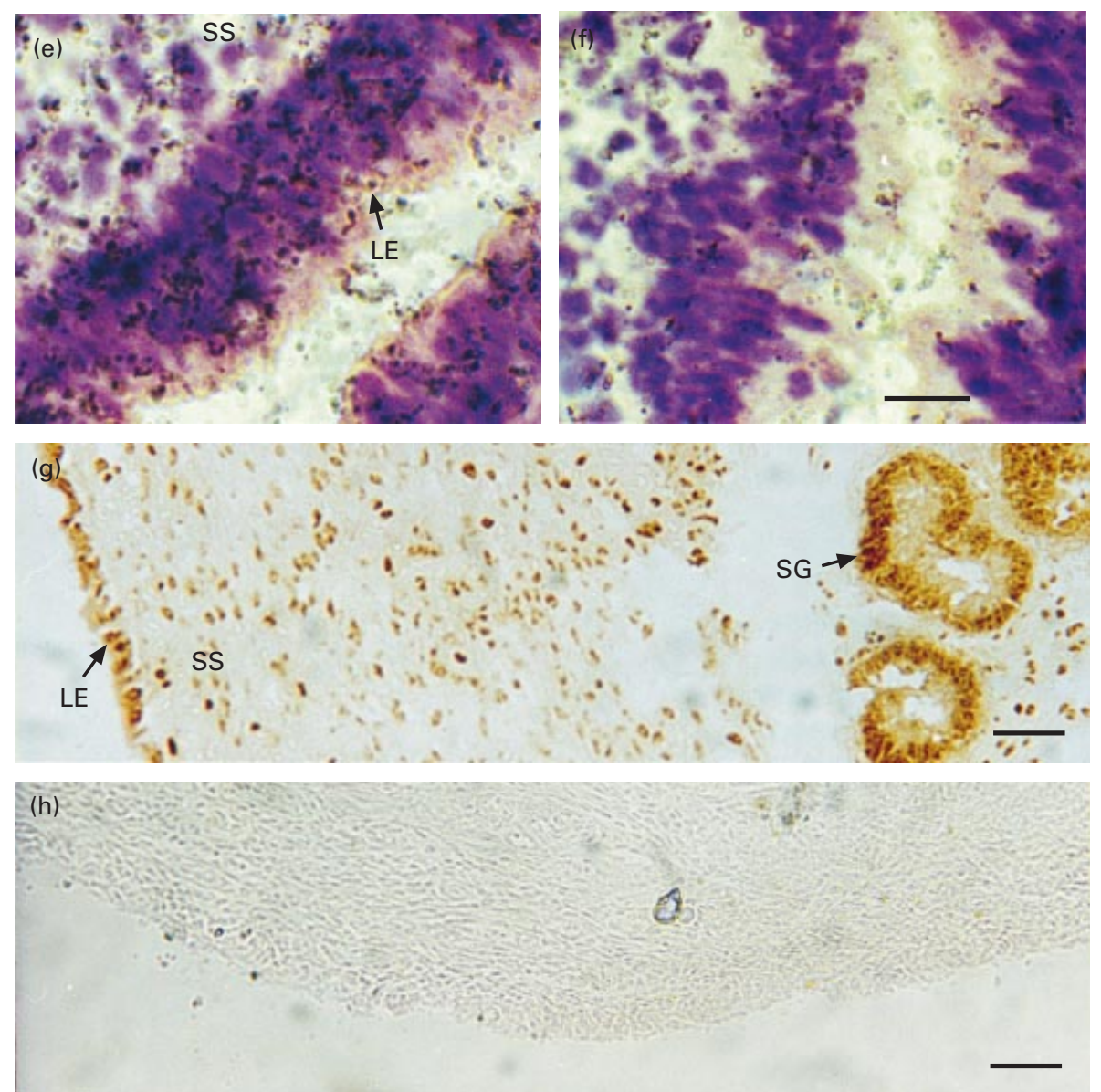

Fig. 2. Localization of oestrogen receptor $\alpha \mathrm{mRNA}$ and protein in the bovine endometrium. (a) Antisense autoradiograph showing localization of oestrogen receptor $\alpha$ mRNA by in situ hybridization in an endometrial biopsy sample collected from an oestrous cow. There is expression in the luminal epithelium and superficial glands. (b) The corresponding sense control section showed no specific hybridization. (c,d) Oestrogen receptor $\alpha$ mRNA in the 
tions in the superficial glands were temporally regulated throughout the oestrous cycle $(P<0.05)$ (Fig. 3a). There was a similar tendency in the variation of oestrogen receptor $\alpha$ mRNA concentrations in the luminal epithelium throughout the oestrous cycle, but this failed to achieve significance (Fig. 3b). In both regions, oestrogen receptor $\alpha$ mRNA concentrations increased at oestrus (day 0), decreased on day 2 and increased again during the early luteal phase (approximately days $4-10$ ). Oestrogen receptor $\alpha$ mRNA concentrations were at their lowest values on days 12-16 in the mid- to late luteal phases, and values started to increase towards their oestrous concentrations from about day 16 . It was difficult to localize the deep glands accurately from the autoradiographs and so the concentrations of oestrogen receptor $\alpha$ mRNA in this region were not determined. Oestrogen receptor $\alpha$ mRNA was also present in the subepithelial stroma but this was not quantified.

Oestrogen receptor $\alpha$ protein was similarly localized to the luminal epithelium and the epithelial cells of both the superficial and deep glands (Fig. 2g). In the luminal epithelium, the expression of oestrogen receptor $\alpha$ was temporally regulated throughout the oestrous cycle (Fig. 3c, $P<0.05$ ) and maximum expression was observed at oestrus and during the mid-luteal phase (days 10-14). Nadirs in oestrogen receptor $\alpha$ concentrations were observed on days 6 and 16. After day 16, the concentration of oestrogen receptor $\alpha$ increased towards oestrous values. In the superficial glands, oestrogen receptor $\alpha$ protein was highest on days 0 and 2, and lower concentrations were observed on days 4-16. Concentrations increased again through the follicular phase (Fig. 3d). In the deep glands, maximum expression also occurred on days 0-2 of the cycle. Although the maximum expression was followed by a slight decrease, concentrations in this region remained high throughout the oestrous cycle (Fig. 3e). There was a similar pattern of oestrogen receptor $\alpha$ expression in the subepithelial stroma (data not shown).

\section{Oestrogen receptor $\alpha$ expression during early pregnancy}

In Expt 2, oestrogen receptor $\alpha$ mRNA was localized in the bovine uterus on days 12-18 of the oestrous cycle or pregnancy using in situ hybridization. Oestrogen receptor $\alpha$ mRNA was detected at low to moderate concentrations in the luminal epithelium and superficial glands and at moderate concentrations in the deep glands (Fig. 2c,d). The concentrations of oestrogen receptor $\alpha$ mRNA and protein in the deep glands were significantly greater than they were in the luminal epithelium $(P<0.001)$ and superficial glands $(P<0.001)$. There was a significant pregnancy $X$ day interaction for oestrogen receptor $\alpha$ mRNA expression in the luminal epithelium $(P<0.001)$, superficial glands $(P<0.05)$ and subepithelial stroma $(P<0.01)$. In nonpregnant cows, the first detectable increase in oestrogen receptor $\alpha$ mRNA was on day 16, and concentrations remained high on day 18 in all uterine regions except the deep glands (Fig. 4). In pregnant cows, the concentration of oestrogen receptor $\alpha$ mRNA was similar to that of the nonpregnant group on days 12 and 14 in the luminal epithelium and subepithelial stroma, and on day 12 in the deep glands. Concentrations decreased subsequently in all regions in the pregnant cows and were undetectable in all regions except in the caruncles (data not shown) by day 18 .

\section{Progesterone receptor expression throughout the oestrous cycle}

Progesterone receptor mRNA was expressed mainly in the subepithelial stroma and superficial glands throughout the oestrous cycle (Fig. 5a,c), and was also localized to the luminal epithelium, but at much lower concentrations (Fig. 5). Progesterone receptor mRNA expression was temporally regulated throughout the oestrous cycle in both the subepithelial stroma $(P<0.01)$ and superficial glands $(P<$ 0.05) (Fig. 6a,b). In both the subepithelial stroma and superficial glands, progesterone receptor mRNA was expressed in moderate amounts at oestrus and expression was maintained at this level during the early luteal phase. In both these regions, the amounts of progesterone receptor mRNA started to decrease between days 8 and 10 and remained low throughout the rest of the luteal phase. On days 15-16, the concentrations of progesterone receptor mRNA in both the subepithelial stroma and superficial glands started to increase and by day 21 were similar to concentrations recorded at oestrus (day 0).

In the endometrial biopsy samples (Fig. 5e,g), progesterone receptor was localized to the nucleus of the superficial glands and subepithelial stroma cells throughout the oestrous cycle. In the luminal epithelium, progesterone receptor was localized to the nucleus only on day 6 in two out of three cows (Fig. 5e). However, there was specific immunostaining along the apical surface of the luminal epithelium. This specific apical surface immunostaining was also observed in the superficial glands on days 12-14 (Fig. 5f). The intensity of the apical surface immunostaining in the luminal epithelium changed during the oestrous cycle

bovine uterus on day 14 in a (c) non-pregnant or (d) pregnant cow. In both the non-pregnant and pregnant animals, there is moderate expression of oestrogen receptor $\alpha$ mRNA in the luminal epithelium and superficial glands and high expression in the deep glands. (e) Antisense and (f) sense section of non-pregnant uterus at day 14 coated with photographic emulsion and counterstained with haematoxylin and eosin, showing strong expression of oestrogen receptor $\alpha$ mRNA in the luminal epithelium and low expression in the subepithelial stroma. (g) Immunocytochemical localization of oestrogen receptor $\alpha$ in the endometrium from a biopsy sample from an oestrous cow. There was strong staining in the nuclei of the luminal epithelium, subepithelial stroma and superficial gland cells. (h) Corresponding control section treated with mouse IgG. DG: deep gland cell; LE: luminal epithelium; M: myometrium; SG: superficial gland; SS: subepithelial stroma. Scale bars represent (a-d) $2.5 \mathrm{~mm},(\mathrm{e}, \mathrm{f}) 2 \mu \mathrm{m}$ and $(\mathrm{g}, \mathrm{h}) 10 \mu \mathrm{m}$. 

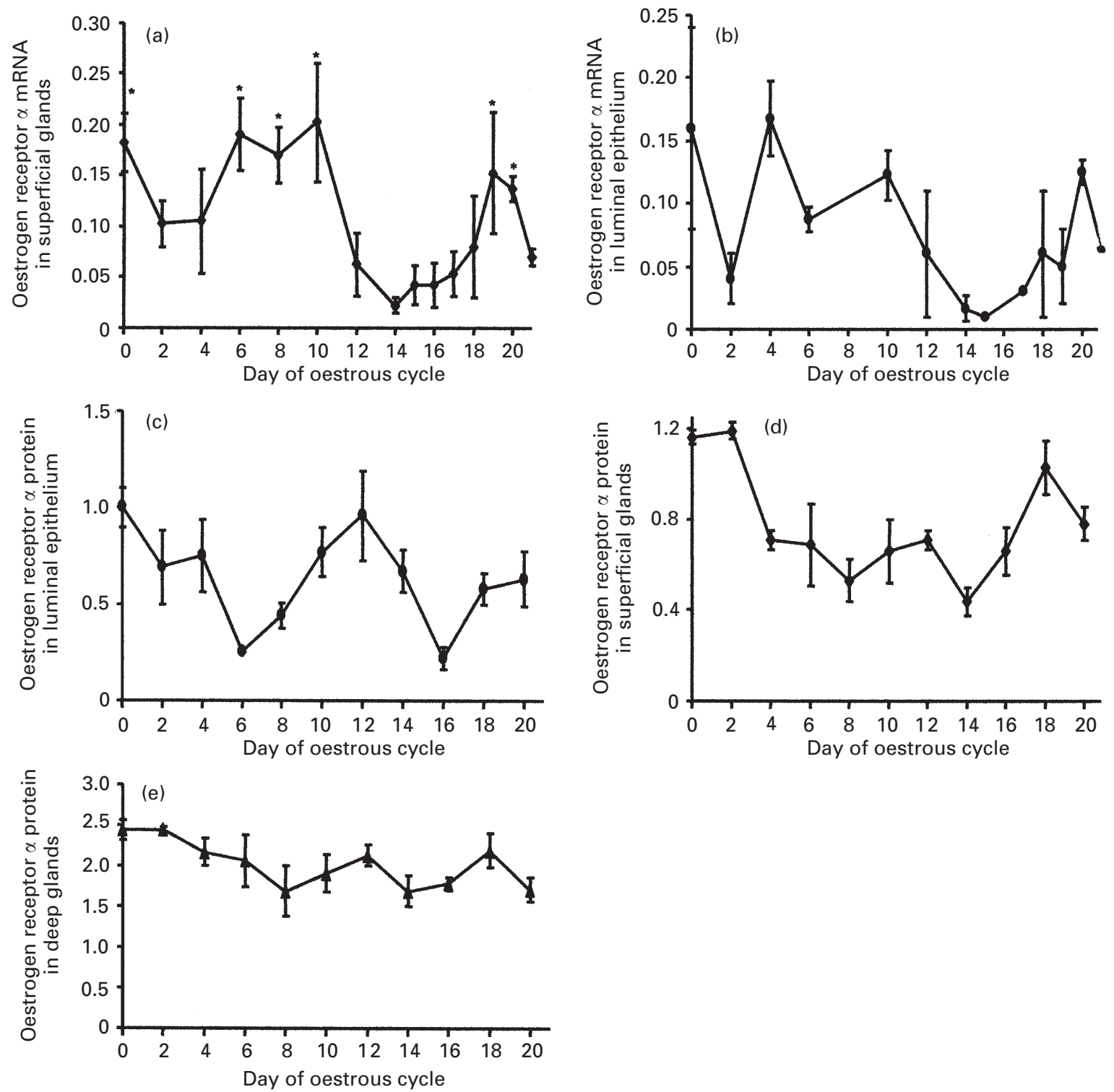

Fig. 3. Expression of oestrogen receptor $\alpha$ mRNA and protein in bovine endometrial biopsy samples throughout the oestrous cycle. $(a, b)$ Expression of oestrogen receptor $\alpha$ mRNA in the superficial glands and luminal epithelium, respectively. Values are the mean \pm SEM absorbance units as measured from autoradiographs ( $n=3-4$ cows per day). In the superficial glands, there was a significant day effect $(P<0.05)$ : all values significantly greater than the lowest day (day 14) are indicated with an asterisk. In the luminal epithelium, day had a significance of $P=0.07$. (c,d) Corresponding concentrations of oestrogen receptor $\alpha$ in the nuclei of the luminal epithelium and superficial glands, respectively, and also (e) in the deep glands. Values were scored on a range of 0 (undetectable) to 4 (intense) staining and are the mean \pm SEM of three or four cows per time point. There were significant day of oestrous cycle effects in all cases $(P<0.05)$ but comparisons were not made between individual days.

$(P<0.05)$ : the lowest intensity of staining was observed during pro-oestrus and the highest intensity staining on day 12 (Fig. 6c). The expression of progesterone receptor protein was temporally regulated in both the superficial glands $(P<0.05)$ and subepithelial stroma $(P<0.05)$. In the superficial glands, the concentration of progesterone receptor was low at oestrus, increased during the early luteal phase and reached a peak value on days $6-8$. The large variability seen over this period was probably due to peak values occurring on slightly different days in different cows. After day 8, progesterone receptor concentrations gradually decreased and became undetectable from day 12 to day 20 (Fig. 6d). In the subepithelial stroma, the highest expression of progesterone receptor was observed from day 0 to day 8 and the lowest expression was during the mid- to late luteal phase (Fig. 6e). Progesterone receptor expression was not 
examined in Expt 2 as the results of Expt 1 showed that values were very low at the times samples were collected (days 12-18).

\section{Oxytocin receptor expression throughout the oestrous cycle}

Oxytocin receptor mRNA was localized to the luminal epithelium and superficial glands at oestrus (Fig. 7a,c). Oxytocin receptor mRNA was expressed in a cyclical manner in both the luminal epithelium and superficial glands $(P<$ 0.001 ) and the highest expression was observed at oestrus (Fig. 8a,b). After oestrus, oxytocin receptor mRNA concentrations decreased and were undetectable between day 6 and day 15 . Oxytocin receptor mRNA concentrations became detectable again in the luminal epithelium of one of the four cows on day 16 and in the remaining three cows on day 17 , when they were also first apparent in the superficial glands. Oxytocin receptor mRNA concentrations continued to increase during the follicular phase and on day 21 returned to concentrations similar to those observed at oestrus.

\section{Oxytocin receptor expression during early pregnancy}

In Expt 2, no oxytocin receptor mRNA was detectable on day 12 , although it was present in the luminal epithelium of two of five non-pregnant animals on day 14 and in three of four non-pregnant cows on day 16, at which time oxytocin receptor mRNA expression had spread to the superficial glands (Fig. 7e,g). There was a significant day effect on oxytocin receptor mRNA concentrations, and the highest concentrations were observed on day $18(P<0.01)$ (Fig. 8c). Expression of oxytocin receptor mRNA was undetectable in all the pregnant animals during this period (Fig. 7f), except for in one pregnant cow at day 18, in which the oxytocin receptor mRNA concentration of 0.27 absorbance units was similar to the oxytocin receptor concentrations observed in the non-pregnant cows at day 18 (Fig. 8c). The embryo collected from this cow presumably was not secreting sufficient interferon $\tau$ to prevent oxytocin receptor upregulation. This animal was omitted from the steroid receptor analysis. In the cow with detectable oxytocin receptor mRNA on day 18 , the concentrations of oestrogen receptor $\alpha$ mRNA were similar to those in the luminal epithelium of the non-pregnant group at day 18 (absorbance $=0.09$ versus $0.07 \pm 0.02$ )

\section{Discussion}

This study examined the expression patterns of oxytocin receptor, oestrogen receptor $\alpha$ and progesterone receptor mRNAs and their proteins in the bovine endometrium and showed that the localization of all three receptors was influenced by both the stage of the oestrous cycle and pregnancy. By comparing the temporal patterns of the different receptors, this work has provided insights into the possible regulation of their expression.
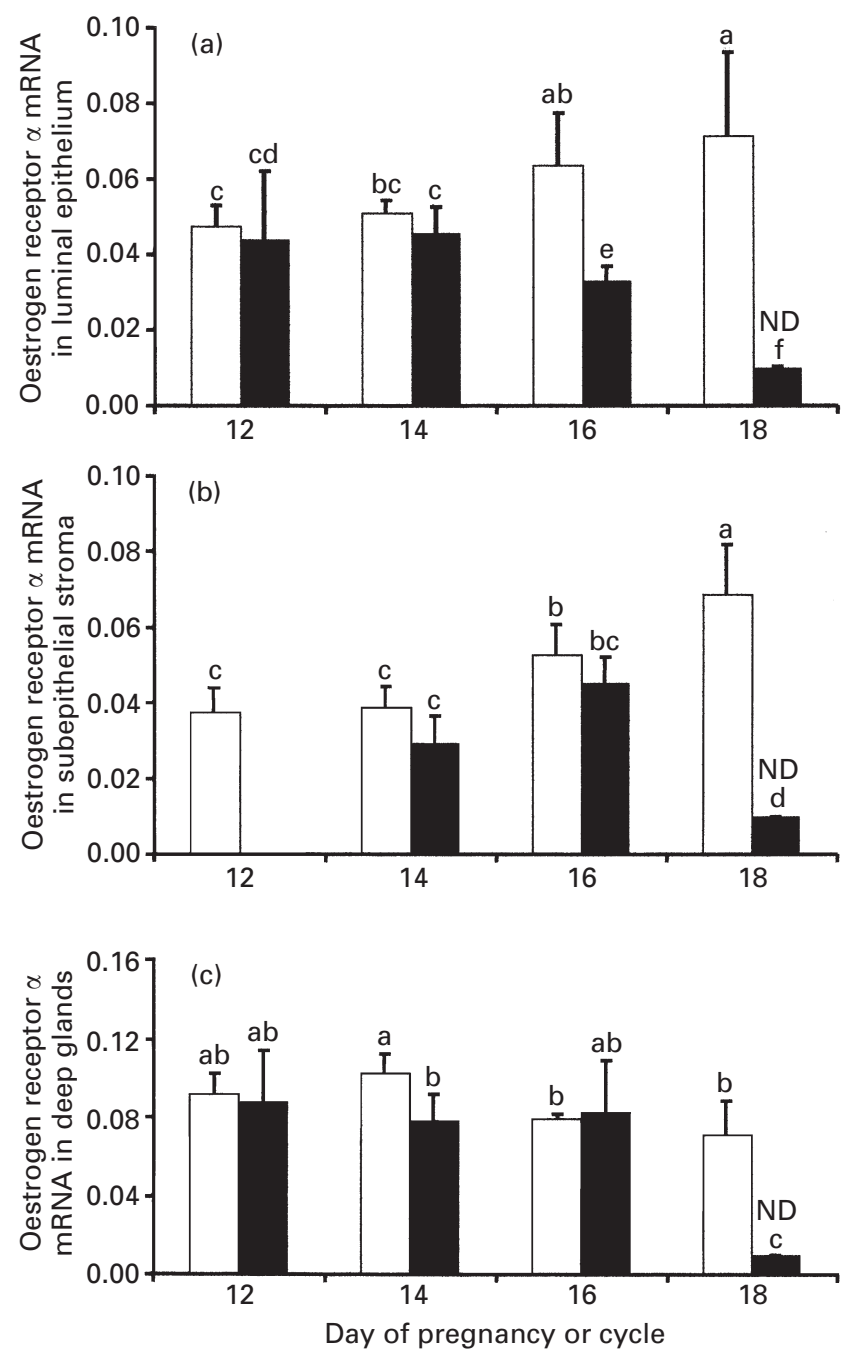

Fig. 4. Expression of oestrogen receptor $\alpha$ mRNA in (a) luminal epithelium, (b) subepithelial stroma and (c) the deep glands of pregnant $(\square)$ and non-pregnant $(\square)$ cows on days $12-18$ of the oestrous cycle or early pregnancy. The number of animals in each group is given (Table 1). The values are the mean \pm SEM absorbance units as measured from autoradiographs. ND: not detectable $(<0.01)$. Bars with different letters are significantly different: $\mathrm{a}>\mathrm{b}>\mathrm{c}>\mathrm{d}>\mathrm{e}>\mathrm{f} ; \mathrm{P}<0.05$.

The concentrations of both oestrogen receptor $\alpha$ and progesterone receptor mRNA and protein were generally high at oestrus and low during the luteal phase. This finding is consistent with those of a number of other studies in cows (Hendricks and Harris, 1978; Meyer et al., 1988; Boos et al., 1996) and sheep (Cherny et al., 1991; Wathes and Hamon, 1993; Spencer and Bazer, 1995) and supports the hypothesis that oestradiol has a stimulatory effect on expression of oestrogen receptor $\alpha$ and progesterone receptor, whereas progesterone is generally inhibitory (Wathes et al., 1996; Ing and Tornesi, 1997). This conclusion is supported by the report by Xiao and Goff (1998) that oestradiol increases oestrogen 
(a)
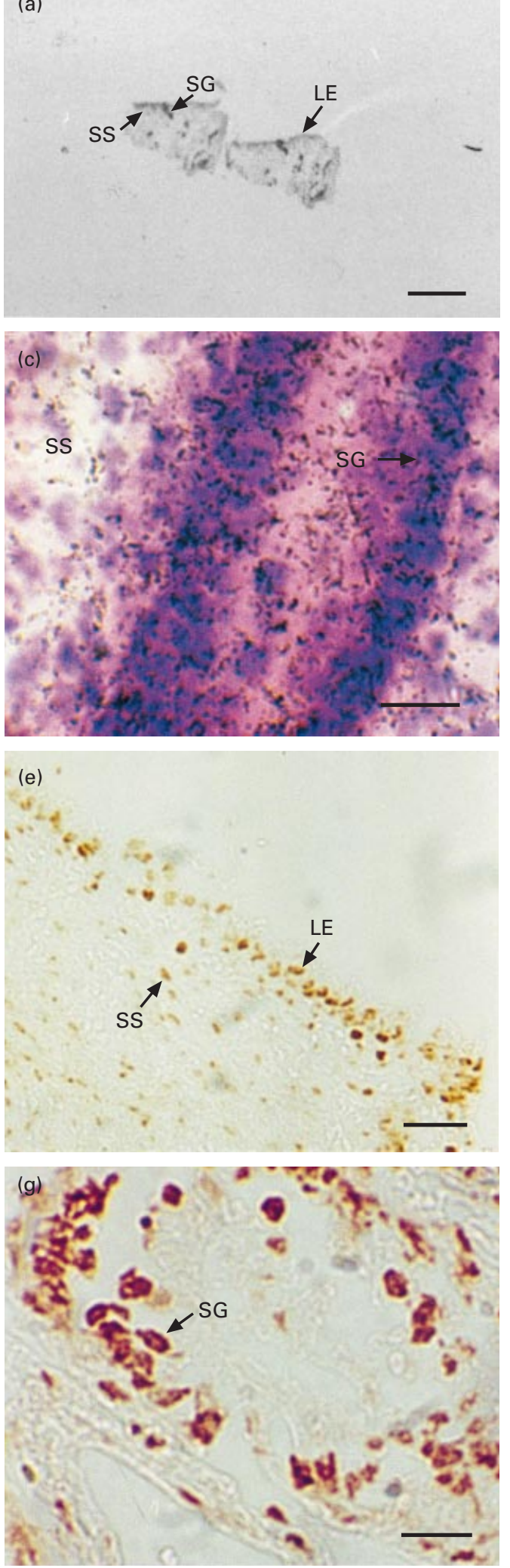

(b)
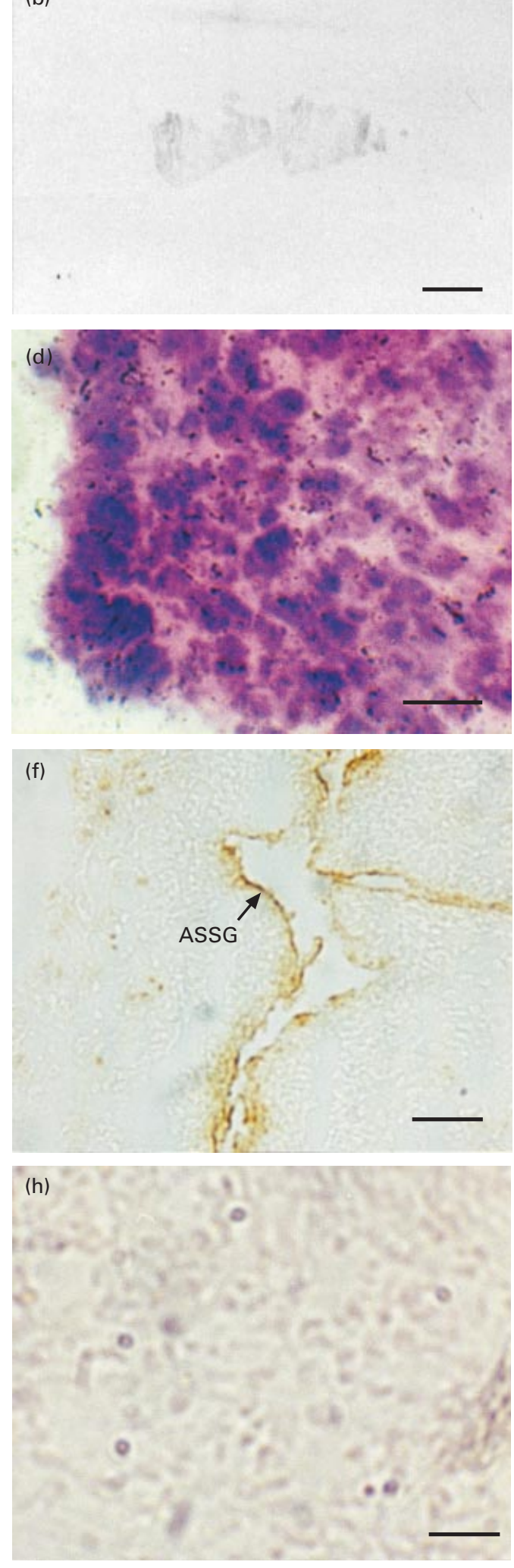

Fig. 5. Localization of progesterone receptor mRNA and protein in the bovine endometrium. (a) Antisense autoradiograph showing localization of progesterone receptor mRNA by in situ hybridization in an endometrial biopsy sample collected from a cow on day 6 of the oestrous cycle. There is low expression in the luminal epithelium and subepithelial stroma and higher expression in the superficial glands. 
receptor $\alpha$ and progesterone receptor concentrations in a dose dependent manner in bovine epithelial and stromal cells in culture.

The expression of oestrogen receptor $\alpha$ during the oestrous cycle had several notable exceptions to the general situation described above. (1) Oestrogen receptor $\alpha$ concentrations in the luminal epithelium reached peak values of similar magnitude at both oestrus and in the midluteal phase. Boos et al. (1996) reported that oestrogen receptor $\alpha$ in the luminal epithelium was greater on day 14 compared with day 7 in bovine luminal epithelium. In contrast, previous studies in sheep found that concentrations of oestrogen receptor $\alpha$ in the luminal epithelium are low throughout the luteal phase and increase only during the follicular phase (Wathes and Hamon, 1993; Spencer and Bazer, 1995). This finding indicates that oestrogen receptor $\alpha$ concentrations remain higher in the luminal epithelium during the luteal phase in cows than they do during this phase in ewes. (2) In the superficial glands, the expression patterns for oestrogen receptor $\alpha$ mRNA and protein were different: oestrogen receptor $\alpha$ mRNA increased during the early luteal phase when oestrogen receptor $\alpha$ protein concentrations were declining. This finding indicates that oestrogen receptor $\alpha$ expression is controlled posttranscriptionally as was suggested by Ing et al. (1996) after studies in which oestradiol was administered to ovariectomized sheep. (3) In agreement with previous studies in sheep (Wathes and Hamon, 1993; Spencer and Bazer, 1995), the expression of oestrogen receptor $\alpha$ in the deep glands was maintained at high concentrations throughout the oestrous cycle. These receptors may be required to stimulate glandular secretions or to relay information on plasma oestradiol concentrations to the other types of endometrial cell via paracrine interactions.

In both the present and a previous study (Xiao and Goff, 1998), progesterone receptor concentrations were found to be higher in the bovine uterine stroma compared with those in the epithelial cells, and expression in the subepithelial stroma was highest between oestrus and day 8 and lowest during the mid- and late luteal phases. Previous reports have demonstrated similar expression patterns for progesterone receptor and progesterone binding sites in this region in cows (Meyer et al., 1988; Boos et al., 1996) and sheep (Spencer and Bazer, 1995). In the luminal epithelium, progesterone receptor mRNA expression was very low throughout the oestrous cycle. Furthermore, progesterone receptor was detected in the nucleus of the luminal epithelium cells only on day 6 (in two of three cows) and was not detected at all other times. Previous reports have also shown that progesterone receptor in the luminal epithelium reaches maximum concentration on days 6-8 and that it is generally not detectable at other stages of the oestrous cycle (cows: Boos et al., 1996; sheep: Wathes and Hamon, 1993; Spencer and Bazer, 1995). However, specific immunostaining along the apical surface of the luminal epithelium (and occasionally the superficial glands) was observed in the present and a previous study (Robinson et al., 1999), and the highest intensity of staining was recorded on day 12. In sheep, Wathes and Hamon (1993) also showed specific immunostaining along the apical luminal epithelium surface using a different antibody to progesterone receptor. The immunostaining may represent progesterone receptors on the membrane surface. Specific non-genomic membrane binding sites for progesterone have been identified in the bovine corpus luteum (Rae et al., 1998) and in human spermatozoa (Luconi et al., 1998). There were slightly different expression patterns for progesterone receptor $\mathrm{mRNA}$ and protein in the superficial glands; progesterone receptor mRNA concentrations increased during the follicular phase but the increase in progesterone receptor did not occur until after oestrus. This finding indicates that there was post-transcriptional control of progesterone receptor concentrations, and is in agreement with the results of a study in ewes by Spencer and Bazer (1995).

The expression of oxytocin receptor mRNA was regulated cyclically. The highest expression of oxytocin receptor mRNA was observed at oestrus and the lowest (not detectable) expression was observed during the luteal phase. These findings are in strong agreement with other studies of oxytocin receptor mRNA and protein concentrations in cows (Meyer et al., 1988; Fuchs et al., 1990; Jenner et al., 1991; Cerbito et al., 1997) and sheep (Ayad et al., 1991; Wathes and Hamon, 1993; Stevenson et al., 1994). Several studies in cows used radioreceptor assays to demonstrate that the increase in oxytocin receptor occurred on day 15 (Fuchs et al., 1990; Jenner et al., 1991; Mann and Lamming, 1994). Furthermore, injection of oxytocin into non-pregnant cows failed to release $\mathrm{PGF}_{2 \alpha}$ on day 15 but did so on day 16 (Lamming and Mann, 1995). In the present study, oxytocin receptor was first observed in the luminal epithelium on day 16 (Expt 1) and day 14 (Expt 2). In Expt 1, oxytocin receptor appeared before any

(b) Corresponding sense control section showing no specific hybridization. (c) Antisense and (d) sense section of day 6 biopsy sample coated with photographic emulsion and counterstained with haematoxylin and eosin, showing strong expression of progesterone receptor mRNA in the superficial glands and low expression in the subepithelial stroma. (e) Immunocytochemical localization of progesterone receptor in the endometrium from a biopsy sample from a cow on day 6 of the oestrous cycle. There was strong staining in the nuclei of the luminal epithelium and subepithelial stroma cells. (f) Immunocytochemical localization of progesterone receptor in a day 12 biopsy sample showing specific staining of the apical surface of a superficial gland. (g) Immunocytochemical localization of progesterone receptor in a day 6 biopsy sample showing specific staining in the nuclei of the superficial glands. (h) Corresponding control section treated with mouse IgG. ASSG: apical surface of a superficial gland; LE: luminal epithelium; SG: superficial gland; SS: subepithelial stroma. Scale bars represent (a,b) $2.5 \mathrm{~mm},(\mathrm{c}, \mathrm{d}, \mathrm{g}, \mathrm{h}) 2 \mu \mathrm{m},(\mathrm{e}) 10 \mu \mathrm{m}$ and (f) $5 \mu \mathrm{m}$. 

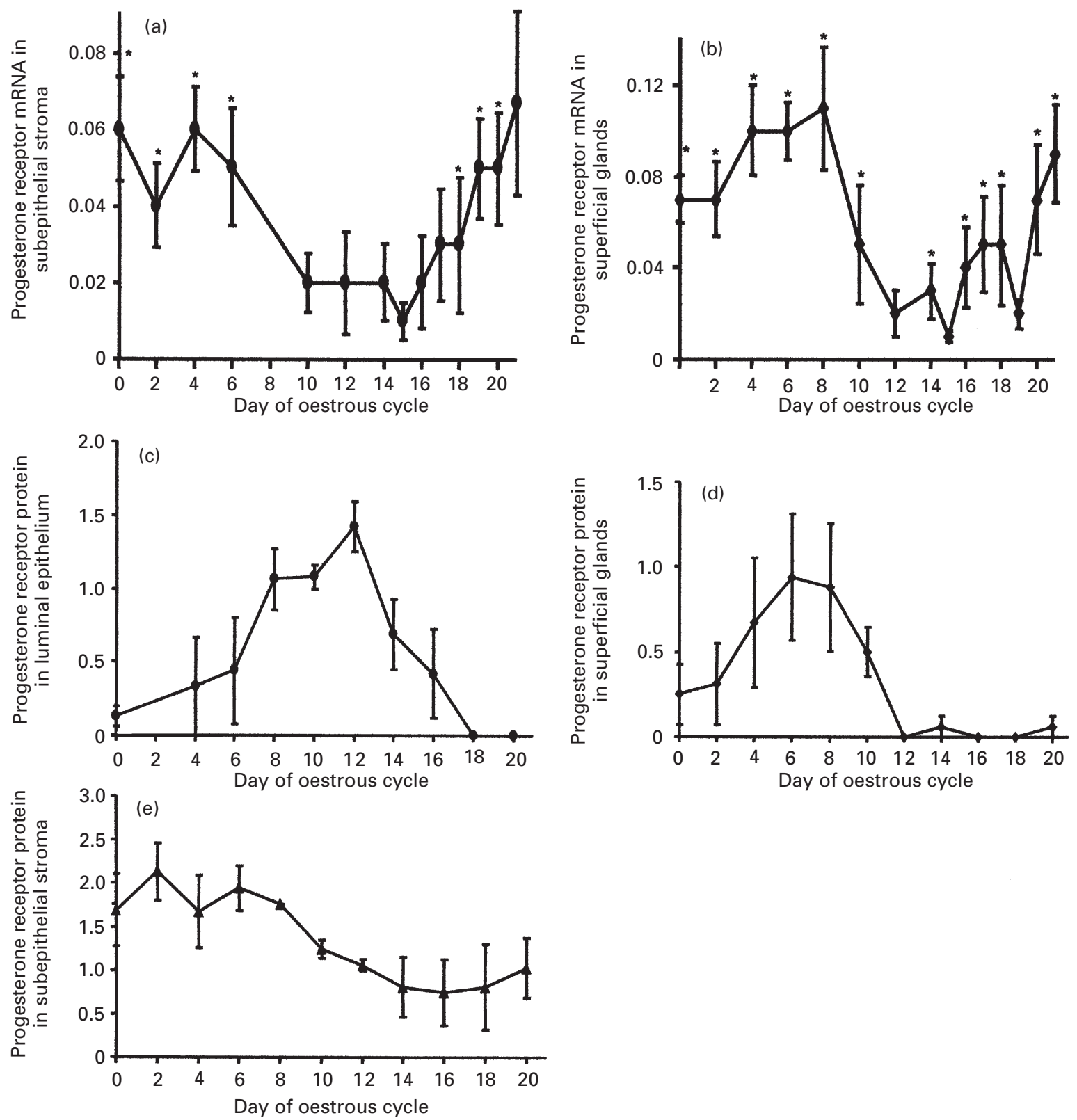

Fig. 6. Expression of progesterone receptor $m R N A$ and protein in the bovine endometrium throughout the oestrous cycle. $(a, b)$ Expression of progesterone receptor mRNA in the subepithelial stroma underlying the luminal epithelium and superficial glands, respectively. The values are the mean \pm SEM absorbance units $(n=3-4$ cows per day). In both regions, there was a significant day effect $(P<0.05)$ and all values significantly greater than the lowest value (day 15$)$ are marked with an asterisk $(P<0.05)$. (c-e) Progesterone receptor concentrations measured in the luminal epithelium, superficial glands and subepithelial stroma. In the luminal epithelium, staining was localized to the apical surface of the cells whereas in the superficial glands and subepithelial stroma it was present in the cell nuclei as expected. On days 12-14, there was also staining along the apical surface of the superficial glands. Values were scored on a range of 0 (undetectable) to 4 (intense) staining and are the mean \pm SEM of three or four time points. There were significant day of oestrous cycle effects in all cases $(P<0.05)$ but comparisons were not made between individual days.

changes in plasma concentrations of progesterone or oestradiol, indicating that the upregulation of oxytocin receptor was not the result of changes in plasma steroid hormone concentrations.

In Expt 1, oxytocin receptor mRNA concentrations started to decrease again immediately after oestrus in both the luminal epithelium and superficial glands, preceding the increase in circulating progesterone. This finding may be related to the decreasing oestradiol concentrations observed after oestrus (Lamming and Mann, 1995). 
However, during the early luteal phase, the continued suppression of oxytocin receptor is likely to be attributable to progesterone acting through progesterone receptors, which are present at high concentrations in the stroma at this time. Several studies have demonstrated that progesterone alone can suppress oxytocin receptor expression in ovariectomized animals (cows: Lamming and Mann, 1995; sheep: Vallet et al., 1990; Fairclough and Lau, 1992; Cann et al., 1994; Wathes et al., 1996) and reduce oxytocin binding in ovine endometrial cultures (Sheldrick and Flick-Smith, 1993; Abayasekara et al., 1995), although the reduction of oxytocin binding in ovine endometrial cultures may be a consequence of progesterone inhibiting the direct binding of oxytocin to oxytocin receptor (Grazini et al., 1998). The action of progesterone is probably indirect, as no progesterone response element has been identified in the bovine oxytocin receptor gene promoter (Bathgate et al., 1995) and progesterone does not suppress oxytocin receptor expression in cultured bovine epithelial cells (Horn et al., 1998).

The exact mechanism whereby oxytocin receptor expression is subsequently upregulated in the uterus is not understood. Uterine oxytocin receptor concentrations increase in ovariectomized animals when they are treated with progesterone for longer than 10 days (cows: Lamming and Mann, 1995; sheep: Vallet et al., 1990; Fairclough and Lau, 1992; Beard and Lamming, 1994; Wathes et al., 1996). One explanation for progesterone losing its inhibitory effect is that it downregulates its own receptor (McCracken et al., 1999). However, in Expt 1, progesterone receptor concentrations decreased between day 8 and day 10 in the stroma and glands but oxytocin receptor upregulation did not begin until day 16, at least 6 days after progesterone receptor expression had returned to basal values. It is likely that the suppressive effect of progesterone receptor has to be removed before oxytocin receptor concentrations can increase, but this factor alone does not cause the induction of oxytocin receptor upregulation. However, the apical surface staining for progesterone receptor along the luminal epithelium started to decline on day 12 and was undetectable by day 18 . Whether this decrease in progesterone receptor is a signal for oxytocin receptor upregulation warrants further investigation.

An alternate hypothesis is that oestradiol acting via oestrogen receptor $\alpha$ induces the upregulation of oxytocin receptor, as administration of oestrogen to both cyclic (midluteal phase) and ovariectomized ewes in vivo leads to an increase in endometrial oxytocin receptor concentrations (sheep: Hixon and Flint, 1987; Spencer et al., 1995a,b; goats: Cooke et al., 1998). This hypothesis implies that oestrogen receptor $\alpha$ expression is upregulated before change in oxytocin receptor gene expression occurs. In Expt 1 , oestrogen receptor $\alpha$ in the luminal epithelium increased between day 16 and day 18, slightly after oxytocin receptor upregulation. Furthermore, in Expt 2, oxytocin receptor mRNA was first detectable on day 14 , whereas the first significant increase in oestrogen receptor $\alpha$ mRNA did not occur until day 16 . In ewes, the precise relationship between the timing of oestrogen receptor $\alpha$ and oxytocin receptor upregulation is equivocal. The results of one study indicate that oestrogen receptor $\alpha$ concentrations increase before oxytocin receptor concentrations (Spencer et al., 1998), whereas the results of another study indicate the reverse (Wathes and Hamon, 1993). It may be that the upregulation of oxytocin receptor does not require upregulation of oestrogen receptor $\alpha$ in the luminal epithelium, but is mediated by paracrine actions through oestrogen receptor $\alpha$ in the deep glands.

There is considerable evidence that oestradiol is not essential for oxytocin receptor upregulation and that oxytocin receptor may be constitutively expressed in the epithelial cells. For example, oxytocin receptor mRNA is present in the luminal epithelium of ovariectomized ewes (Wathes et al., 1996) and oxytocin receptor develops spontaneously in endometrial explants and dispersed epithelial cells in the absence of steroids (Sheldrick and Flick-Smith, 1993; Horn et al., 1998; Leung and Wathes, 2000). Although there is an oestrogen receptor response element (ERE) in the coding region of the oxytocin receptor gene and three half-palindromic ERE sites in the 5' promoter, preliminary binding studies in vitro indicate that oestrogen receptor $\alpha$ does not bind to these sites (Bathgate et al., 1998). Collectively, these results indicate that oestradiol is not essential for the initial development of oxytocin receptor in the luminal epithelium, although it may speed up the process (Leung and Wathes, 2000) and assist the spread of oxytocin receptor to other types of cell once luteolysis has been initiated.

The present study has also provided additional information on the regulation of endometrial oestrogen receptor $\alpha$ and oxytocin receptor concentrations in early bovine pregnancy. The presence of an embryo had no effect on oestrogen receptor $\alpha$ mRNA concentration on days 12-14 in the luminal epithelium, superficial glands or subepithelial stroma. However, on days 16-18, oestrogen receptor $\alpha$ mRNA concentrations increased in the luminal epithelium of non-pregnant cows, whereas they declined during this period in pregnant cows, becoming undetectable on day 18 . Robinson et al. (1999) reported no difference in the concentrations of oestrogen receptor $\alpha$ mRNA between pregnant and non-pregnant cows on day 16, possibly reflecting slightly different cycle durations between the animals in the two studies. Hendricks and Harris (1978) also found that the concentration of oestradiol binding sites in the pregnant bovine endometrium was similar to that in non-pregnant controls on days 13-14. Therefore, endometrial oestrogen receptor $\alpha$ concentrations are downregulated during early bovine pregnancy, presumably through the actions of interferon $\tau$ as discussed below, but not until days 16-18.

No oxytocin receptor mRNA was detected in the pregnant endometrium on days 12-18 except in one pregnant cow on day 18, which would presumably have undergone luteolysis and returned to oestrus. A significant difference in 

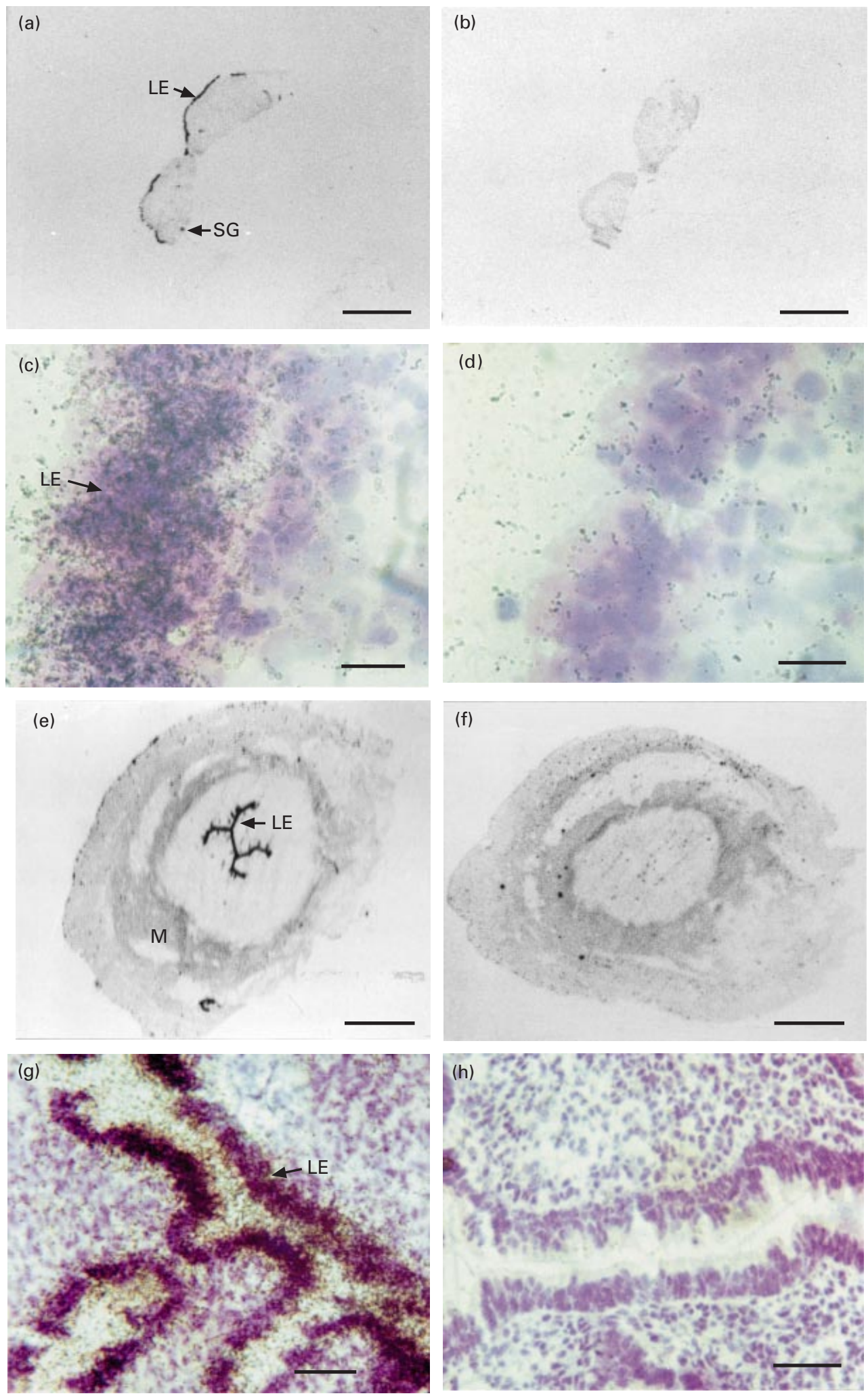

Fig. 7. Localization of oxytocin receptor mRNA in bovine endometrium. Sections were probed with either antisense $(a, c, e, f, g)$ or sense $(b, d, h)$ oligonucleotides. $(a, b)$ Endometrial biopsy sections from an oestrous cow. There was expression of oxytocin receptor mRNA in the luminal epithelium and superficial glands. (c,d) Section of endometrium from an oestrous cow is coated with photographic 

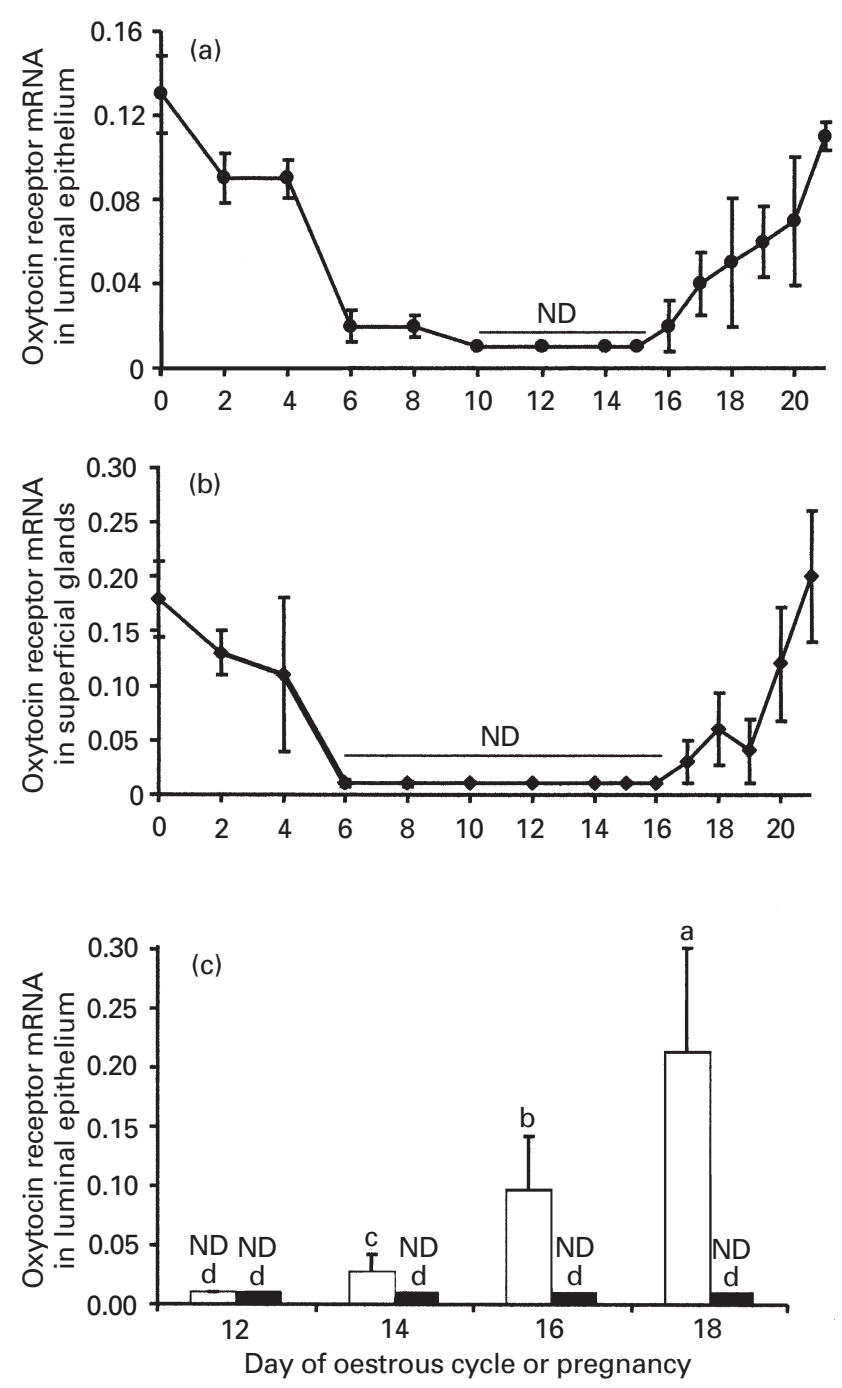

Fig. 8. Expression of oxytocin receptor mRNA in the bovine endometrium throughout the oestrous cycle and early pregnancy. $(a, b)$ Expression in the luminal epithelium and superficial glands, respectively. Values are the mean \pm SEM absorbance units ( $n=3-4$ cows per day). Values were below the detection limit $(\mathrm{ND},<0.01)$ during the mid-luteal phase. In both regions, there was a significant day effect $(P<0.001)$. (c) Expression of oxytocin receptor mRNA in the luminal epithelium on days 12-18 of pregnant $(\square)$ and non-pregnant $(\square)$ cows. Values are mean \pm SEM absorbance units as measured from autoradiographs. The number of animals per time point is given (Table 1). Oxytocin receptor mRNA was not detectable in the pregnant cows. In the nonpregnant cows, the concentrations of oxytocin receptor mRNA increased significantly from day 12 to day $18(P<0.05)$ : $a>b>$ c $>$ d; $P<0.05$. the endometrial oxytocin receptor concentrations between pregnant and non-pregnant animals has been demonstrated during maternal recognition of pregnancy (cows: Fuchs et al., 1990; Jenner et al., 1991; sheep: Ayad et al., 1991; Wathes and Hamon, 1993; Stevenson et al., 1994). Interferon $\tau$, shown to be present in the uterine lumen, presumably suppressed endometrial oxytocin receptor expression. This finding is supported by the observations that recombinant interferon $\tau$ can inhibit the expression of oxytocin receptor both in vivo (Spencer et al., 1995c, 1998; Spencer and Bazer, 1996) and in endometrial explant culture (cows: Horn et al., 1998; Leung et al., 2001; sheep: Abayasekara et al., 1995).

In ewes, it has been hypothesized that the inhibitory action of interferon $\tau$ on oxytocin receptor upregulation is achieved indirectly by inhibiting the upregulation of oestrogen receptor $\alpha$ (Lamming et al., 1995; Spencer et al., 1995a). However, this hypothesis is not supported by the data in cows reported here and previously (Robinson et al., 1999). In Expt 2, endometrial concentrations of oestrogen receptor $\alpha$ mRNA did not start to decrease until day 16 of pregnancy, whereas oxytocin receptor mRNA had started to increase on day 14 in non-pregnant cows, indicating that the downregulation of oestrogen receptor $\alpha$ did not precede the oxytocin receptor upregulation. Interferon $\tau$ may instead act through the interferon $\tau$ type 1 receptor to suppress expression of the oxytocin receptor gene directly. The oxytocin receptor gene promoter region contains an interferon response element (IRE), and interferon regulatory factors (IRF)- 1 and -2 bind to the IRE site (Bathgate et al., 1998). Furthermore, interferon $\tau$ could suppress endometrial oxytocin receptor in bovine endometrial explants cultured in the absence of oestradiol in the medium (Leung et al., 2001).

In conclusion, the expression of oxytocin receptor, oestrogen receptor $\alpha$ and progesterone receptor was generally highest at oestrus and lowest during the luteal phase, indicating that oestradiol has a stimulatory action and progesterone has an inhibitory action on the expression of these genes in cows. However, there are important differences in the control of receptor expression among different types of endometrial cell. In general, the upregulation of oxytocin receptor first occurred in the luminal epithelium on days 16-17, although it was observed as early as day 14 in some cows. However, oestrogen receptor $\alpha$ upregulation did not precede increases in oxytocin receptor gene expression. During early pregnancy, interferon $\tau$ suppressed the expression of both oxytocin receptor and oestrogen receptor $\alpha$.

emulsion and counterstained with haematoxylin and eosin. The silver grains clearly show that the oxytocin receptor mRNA was localized to the luminal epithelium. (e,f) Localization of oxytocin receptor mRNA in the uterus from a (e) non-pregnant or (f) pregnant cow on day 18. Oxytocin receptor mRNA in the luminal epithelium is present only in the non-pregnant cow, although there is low expression in the myometrium in both. (g) Photographic emulsion from a section of endometrium from a non-pregnant cow on day 18 confirming the high specific hybridization in the luminal epithelium. (h) Corresponding sense section is blank. LE: luminal epithelium; M: myometrium; SG: superficial gland. Scale bars represent (a,b,e,f) $2.5 \mathrm{~mm},(\mathrm{c}, \mathrm{d}) 2 \mu \mathrm{m}$ and (g,h) $5 \mu \mathrm{m}$. 
The authors thank all the animal technicians at Sutton Bonington for the care of the animals and their help in the collections of the tissue, and Barbara Wilsmore for the preparation of the photographs. The work was supported by the Ministry of Agriculture, Fisheries and Food and the Milk Development Council.

\section{References}

Abayasekara DRE, Sheldrick EL, Flick-Smith HC and Flint APF (1995) Role of protein kinase $\mathrm{C}$ in the inhibitory action of trophoblast interferons on expression of the oxytocin receptor in sheep endometrium Endocrine 3 151-158

Ayad VJ, Matthews EL, Wathes DC, Parkinson TL and Wild ML (1991) Autoradiographical localization of oxytocin receptors in the endometrium during the oestrous cycle of the ewe Journal of Endocrinology 130 199-206

Bathgate R, Rust W, Balvers M, Hartung S, Morley S and Ivell R (1995) Structure and expression of the bovine oxytocin receptor gene DNA and Cell Biology 14 1037-1048

Bathgate RAD, Tillmann G and Ivell R (1998) Molecular mechanism of the bovine oxytocin receptor gene regulation Biology of Reproduction $\mathbf{5 8}$ Supplement 160

Beard AP and Lamming GE (1994) Oestradiol concentration and the development of the uterine oxytocin receptor and oxytocin-induced $\mathrm{PGF}_{2 \alpha}$ release in ewes Journal of Reproduction and Fertility 100 469-475

Boos A, Meyer W, Schwarz R and Grunert E (1996) Immunohistochemical assessment of oestrogen and progesterone receptor distribution in biopsy samples of the bovine endometrium collected throughout the oestrous cycle Animal Reproduction Science 44 11-21

Cann CH, Lau TM, Kerton DJ, Shaw G, Fairclough RJ and Gow CB (1994) The effects of ovariectomy and ovarian steroids on uterine oxytocin receptors in the anoestrous ewe Animal Reproduction Science 36 123-134

Cerbito WA, Miyamoto A, Sauerwein H, Wijayaguwardane MPB, Ohtani M, Takagi M and Sato K (1997) Evidence for uterine horn differences in local concentrations of oxytocin, oxytocin receptor and prostaglandin $\mathrm{F}_{2 \alpha}$ during the estrous cycle and early pregnancy Reproduction in Domestic Animals 32 161-165

Cherny RA, Salamonsen LA and Findlay JK (1991) Immunocytochemical localization of oestrogen receptors in the endometrium of the ewe Reproduction, Fertility and Development 3 321-331

Cooke RG, Ahmad N and Nicholson T (1998) Effect of progesterone and estradiol $17 \beta$ on oxytocin-induced $\mathrm{PGF}_{2 \alpha}$ release and endometrial oxytocin receptor concentrations in ovariectomized goats Prostaglandins and Other Lipid Mediators 55 109-120

Fairclough RJ and Lau TM (1992) Hormonal control of concentrations of endometrial oxytocin receptors in the ewe Journal of Reproduction and Fertility 94 313-320

Flint APF and Sheldrick EL (1983) Evidence for a systemic role for ovarian oxytocin in luteal regression in sheep Journal of Reproduction and Fertility 67 215-225

Flint APF, Lamming GE, Stewart HJ and Abayasekara DRE (1994) The role of the endometrial oxytocin receptor in determining the length of the sterile oestrous cycle and ensuring maintenance of luteal function in early pregnancy in ruminants Philosophical Transactions of the Royal Society London B 344 291-304

Fuchs AR, Behrens O, Helmer H, Liu C-H, Barros CM and Fields LJ (1990) Oxytocin and vasopressin receptor in bovine endometrium and myometrium during the oestrous cycle and early pregnancy Endocrinology 127 629-636

Grazini E, Guillon G, Mouillac B and Zingg HH (1998) Inhibition of oxytocin receptor function by direct binding of progesterone Nature 392 509-512

Haresign W, Foster JP, Haynes NB, Crighton DB and Lamming GE (1975) Progesterone levels following treatment of seasonally anoestrus ewes with synthetic LH-releasing hormone Journal of Reproduction and Fertility 43 269-279

Hendricks DM and Harris RB (1978) Cytoplasmic estrogen receptors and estrogen concentrations in bovine uterine endometrium Endocrinology 103 176-185

Hixon JE and Flint APF (1987) Effects of luteolytic dose of oestradiol benzoate on uterine oxytocin receptor concentrations, phosphoinositide turnover and prostaglandin $F_{2 \alpha}$ secretion in sheep Journal of Reproduction and Fertility $\mathbf{7 9}$ 457-467

Horn S, Bathgate R, Lioutas C, Bracken K and Ivell R (1998) Bovine endometrial epithelial cells as a model system to study oxytocin receptor regulation Human Reproduction Update 4 605-614

Ing NH and Tornesi MB (1997) Estradiol up-regulates estrogen receptor and progesterone gene expression in specific ovine uterine cells Biology of Reproduction 56 1205-1215

Ing NH, Spencer TE and Bazer FW (1996) Estrogen enhances endometrial estrogen receptor gene expression by a post transcriptional mechanisms in the ovariectomised ewe Biology of Reproduction 54 591-599

Jenner LJ, Parkinson TJ and Lamming GE (1991) Uterine oxytocin receptor in cyclic and pregnant cows Journal of Reproduction and Fertility $\mathbf{1 0 5}$ 165-175

Lamming GE and Mann GE (1995) Control of endometrial oxytocin receptors and prostaglandin $\mathrm{F}_{2 \alpha}$ production in cows by progesterone and oestradiol Journal of Reproduction and Fertility 103 69-73

Lamming GE, Wathes DC, Flint APF, Payne JH, Stevenson KR and Vallet JL (1995) Local actions of trophoblast interferons in suppression of the development of oxytocin and oestradiol receptors in ovine endometrium Journal of Reproduction and Fertility 105 165-175

Leung ST and Wathes DC (2000) Oestradiol regulation of oxytocin receptor expression in cyclic bovine endometrium Journal of Reproduction and Fertility 119 287-292

Leung ST, Cheng Z, Sheldrick EL, Derecka K, Flint APF and Wathes DC (2001) The effects of lipopolysaccharide and interleukins- $1 \alpha-2$ and -6 on oxytocin receptor expression and prostaglandin production in bovine endometrium Journal of Endocrinology 168 497-508

Luconi M, Bonaccorsi L, Maggi M, Pecchioli P, Krausz C, Forti G and Baldi E (1998) Identification and characterization of functional non-genomic progesterone receptor on human sperm membrane Journal of Clinical Endocrinology and Metabolism 83 877-885

McCracken JA, Custer EE and Lamsa JC (1999) Luteolysis: a neuroendocrine-mediated event Physiological Reviews 79 263-323

Madigou T, Tiffoche C, Le Gal F, Pelletier J and Thieulant M (1995) Embase sequence Z66555

Madigou T, Tiffoche C, Lazennec G, Pelletier J and Thieulant M (1996) The sheep estrogen receptor: cloning and regulation of expression in the hypothalamus-pituitary axis Molecular and Cellular Endocrinology 121 153-163

Mann GE and Lamming GE (1994) Use of repeated biopsies to monitor endometrial oxytocin receptors in cows Veterinary Record 135 403-405

Mann GE, Lamming GE and Fray MD (1995) Plasma oestradiol during early pregnancy in the cow and the effect of treatment with buserelin Animal Reproduction Science 37 121-131

Mann GE, Lamming GE, Robinson RS and Wathes DC (1999) The regulation of interferon production and uterine hormone receptors during early pregnancy in the cow Journal of Reproduction and Fertility Supplement 54 317-328

Meyer HH, Mittermeier T and Schams D (1988) Dynamics of oxytocin, estrogen and progestin receptors in the bovine endometrium during the estrous cycle Acta Endocrinologica 118 96-104

Rae MT, Menzies GS, McNeilly AS, Woad K, Webb R and Bramley TA (1998) Specific non-genomic, membrane-localized binding sites for progesterone in the bovine corpus luteum Biology of Reproduction $\mathbf{5 8}$ 1394-1406

Robinson RS, Mann GE, Lamming GE and Wathes DC (1999) The effect of pregnancy on the expression of uterine oxytocin, oestrogen and progesterone receptors during early pregnancy in the cow Journal of Endocrinology $16021-33$

Sheldrick EL and Flick-Smith HC (1993) Effect of ovarian hormones on oxytocin receptor concentrations in explants of uterus from ovariectomised ewes Journal of Reproduction and Fertility 97 241-245

Spencer TE and Bazer FW (1995) Temporal and spatial alterations in uterine estrogen receptor and progesterone receptor gene expression during the 
estrous cycle and early pregnancy Biology of Reproduction $\mathbf{5 3}$ $1527-1543$

Spencer TE and Bazer FW (1996) Ovine interferon tau suppresses transcription of the estrogen receptor and oxytocin receptor genes in the ovine endometrium Endocrinology 137 1114-1147

Spencer TE, Becker WC, George P, Mirando MA, Ogle TF and Bazer FW (1995a) Ovine interferon- $\tau$ inhibits estrogen receptor up-regulation and estrogen-induced luteolysis in cyclic ewes Endocrinology $\mathbf{1 3 6}$ 4932-4944

Spencer TE, Becker WC, George P, Mirando MA, Ogle TF and Bazer FW (1995b) Ovine interferon- $\tau$ inhibits estrogen receptor up-regulation and estrogen-induced luteolysis in cyclic ewes Endocrinology $\mathbf{1 3 6}$ 4932-4944

Spencer TE, Ing NH, Ott TL, Mayes JS, Becker WC, Watson GH, Mirando MA and Bazer FW (1995c) Intrauterine injections of ovine interferon- $\tau$ alters oestrogen receptor and oxytocin receptor expression in the endometrium of cyclic ewes Journal of Molecular Endocrinology 15 203-220

Spencer TE, Ott TL and Bazer FW (1998) Expression of interferon regulatory factors one and two in the ovine endometrium: effects of pregnancy and ovine interferon tau Biology of Reproduction 58 1154-1162

Stevenson KR, Riley PR, Stewart HJ, Flint APF and Wathes DC (1994) Localization of oxytocin receptor mRNA in the ovine uterus during the oestrous cycle and early pregnancy Journal of Molecular Endocrinology 12 93-105
Vallet JL, Lamming GE and Batten M (1990) Control of the endometrial oxytocin receptors and uterine response to oxytocin by progesterone and oestradiol in the ewe Journal of Reproduction and Fertility 90 625-634

Wathes DC and Hamon M (1993) Localisation of oestradiol, progesterone and oxytocin receptors in the uterus during the oestrous cycle and early pregnancy of the ewe Journal of Endocrinology 138 479-491

Wathes DC and Lamming GE (1995) The oxytocin receptor, luteolysis and the maintenance of pregnancy Journal of Reproduction and Fertility Supplement 49 53-67

Wathes DC, Flick-Smith H, Leung ST, Stevenson KR, Meier S and Jenkin G (1996) Oxytocin receptor development in the ovine uterus and cervix throughout pregnancy and at parturition as determined by in situ hybridization analysis Journal of Reproduction and Fertility 106 25-31

Xiao CW and Goff AK (1998) Hormonal regulation of oestrogen and progesterone receptors in cultured bovine endometrial cells Journal of Reproduction and Fertility 115 101-109

Received 22 December 2000.

First decision 19 February 2001.

Revised manuscript received 7 September 2001.

Accepted 13 September 2001. 